\title{
PENGARUH MODEL PEMBELAJARAN TREFFINGER TERHADAP KREATIVITAS BERPIKIR KIMIA PADA PESERTA DIDIK KELAS XI DI SMAN 1 SEWON
}

\author{
Khairunnisa $^{1^{*}}$, Asih Widi Wisudawati ${ }^{1}$ \\ 1 Jurusan Pendidikan Kimia, Fakultas Sains dan Teknologi, \\ Uniersitas Islam Negeri Sunan Kalijaga, Indonesia \\ *E-mail: nissaraisa24@gmail.com
}

\begin{abstract}
ABSTRAK
Penelitian ini merupakan jenis penelitian kuasi eksperimen dengan desain non equivalent control group design yang bertujuan untuk mengkaji pengaruh model pembelajaran Treffinger terhadap kreativitas berpikir kimia peserta didik. Kajian pengaruh model pembelajaran Treffinger terhadap hasil tes kreativitas berpikir kimia dilakukan dengan metode tes. Instrumen yang digunakan yaitu soal essay untuk mengukur indikator kreativitas berpikir yaitu kelancaran, orisinil, dan evaluasi. Data pre-test dan post-test selanjutnya diolah untuk mendapatkan data nilai tes kreativitas berpikir kimia. Analisis menggunakan uji statistika parametrik uji t untuk mengkaji pengaruh implementasi model pembelajaran terhadap hasil tes kreativitas berpikir kimia peserta didik. Analisis data skor hasil skala kemampuan kreativitas berpikir dilakukan menggunakan uji statistika non parametrik uji Mann Whitney untuk mengkaji pengaruh implementasi model pembelajaran terhadap skala kemampuan kreativitas berpikir kimia. Hasil penelitian menunjukkan bahwa terdapat pengaruh dari penggunaan model pembelajaran Treffinger terhadap hasil tes kreativitas berpikir kimia dan skala kemampuan kreativitas berpikir kimia peserta didik. Hasil uji statistika terhadap nilai tes kreativitas berpikir kimia diperoleh nlai sig.(2-tailed) sebesar 0,018. Hal ini menunjukkan bahwa terdapat perbedaan rata-rata skor hasil tes kreativitas berpikir kimia peserta didik antara kelas eksperimen dan kelas kontrol. Hasil uji statistika terhadap skala kemampuan kreativitas berpikir peserta didik diperoleh nilai sig. (2-tailed) sebesar 0,004. Hal ini menunjukkan bahwa terdapat perbedaan rata-rata skor skala kemampuan kreativitas berpikir kimia peserta didik antara kelas eksperimen dan kelas kontrol. Dengan demikian penggunaan model pembelajaran Treffinger mampu meningkatkan kreativitas berpikir kimia pada peserta didik..
\end{abstract}

Kata kunci: kelarutan dan $\mathrm{K}_{\mathrm{sp}}$, kreativitas berpikir, dan model pembelajaran Treffinger.

\begin{abstract}
This research is a kind of quasi experimental research with non-equivalent control group design design which aims to examine the influence of Treffinger learning model on the creativity of cognitive thinking of chemistry and student's chemical creativity attitude. The study of the influence of the Treffinger learning model on the results of the chemistry thinking test is done by the test method. The instrument used is essay to measure the indicator of creativity thinking that is smooth, original, and evaluation. Pretest and posttest data are then processed to obtain data on the value of chemistry thinking test. The analysis used statistical test of parametric $t$ test to examine the effect of learning model implementation on the students' creativity thinking thinking test result. While for study of influence of learning model of Treffinger to attitude of chemistry of learners creativity done by self assessment method. The instrument used is a questionnaire. Analysis of scores on the results of the scale of the ability of thinking creativity was done using non parametric statistical test of Mann Whitney test to study the effect of learning model implementation on the scale of the ability of chemical thinking creativity. The results showed that there was an influence from the use of the Treffinger learning model to the results of the chemistry thinking creativity test and the scale of the students' chemical thinking ability of creativity. The result of the statistical test on the value of the chemical thinking creativity test is obtained nlai sig. (2-tailed) of 0.018. This suggests that there is a difference in mean score of students' chemical thinking thinking test scores between the experimental class and the control class. The results of statistical tests on the scale of creativity
\end{abstract}


ability to think learners obtained sig value, (2-tailed) by 0,004. This suggests that there is a difference in the average score of the students 'ability to think creators' chemistry between the experimental class and the control class. Thus the use of Treffinger learning model can improve the creativity of thinking chemistry in learners.

Keyword: solubility and $K_{s p}$, thinking creativity, and Treffinger learning model.

DOI: https://doi.org/10.15575/jtk.v3i1.2325

\section{PENDAHULUAN}

Saat ini pendidikan sudah menjadi salah satu kebutuhan pokok setiap individu. Pendidikan itu sendiri berkaitan dengan banyak komponen, antara lain lembaga pendidikan (sekolah), pendidik, peserta didik, media pembelajaran, sumber belajar, dan lain-lain. Ada beberapa faktor yang mempengaruhi pelaksanaan pendidikan, seperti karakteristik peserta didik, fasilitas pendukung pembelajaran, strategi pembelajaran yang digunakan oleh pendidik, dan lain-lain.

Proses dan penilaian pembelajaran lebih menekankan pada aspek instruksional yang sangat terbatas yaitu pada penguasaan materi. Dengan kata lain, lebih menekankan pada dimensi kognitifnya saja sehingga mengabaikan sisi lain yang penting, yaitu pembentukan watak dan karakter yang sesungguhnya menjadi fungsi tujuan utama pendidikan. Adapun pengelolaan kelas selama ini belum mampu menciptakan suasana yang kondusif untuk berkembangnya pengalaman belajar peserta didik yang dapat menjadi landasan untuk berkembangnya kemampuan intelektual peserta didik (Yunita, 2013: 94-95).

Proses pembelajaran selama ini masih banyak didominasi guru, sehingga peserta didik hanya berperan sebagai pelaksana terhadap perintah guru, peserta didik tinggal menerima pengetahuan dari gurunya. Jika hal tersebut dibiarkan, dikhawatirkan akan berdampak negatif terhadap pengembangan kreativitas peserta didik. Padahal kreativitas penting untuk dipupuk dan dikembangkan, karena kreativitas memang sangat dibutuhkan terutama berkaitan dengan pembangunan Indonesia yang membutuhkan sumber daya manusia berkualitas yang memiliki kreativitas tinggi (Juliantine, 2009:2).

Pendidikan di Indonesia masih kurang memberi peluang bagi pengembangan kreativitas. Ranah di sekolah yang terutama dilatih adalah ranah kognitif yang meliputi pengetahuan, ingatan dan kemampuan berpikir logis atau penalaran. Sementara perkembangan ranah afektif (sikap atau perasaan) dan ranah psikomotorik (keterampilan) serta ranah lainnya kurang diperhatikan dan dikembangkan. Pentingnya kreativitas juga tertera dalam Sistem Pendidikan Nasional No 20 Tahun 2003 yang intinya antara lain adalah melalui pendidikan diharapkan dapat mengembangkan potensi peserta didik agar menjadi manusia yang bertakwa, berakhlak mulia, cakap, kreatif, juga mandiri (Juliantine, 2009:1).

Berdasarkan hasil wawancara dengan peserta didik MAN (Madrasah Aliyah Negeri) 4 Bantul pada tanggal 28 November 2016, diperoleh hasil bahwa pembelajaran di kelas selama ini cukup menyenangkan, akan tetapi ada salah satu mata pelajaran yang cukup sulit yaitu pelajaran kimia. Selain berisi materi yang bersifat hafalan, materi kimia juga bersifat hitungan. Peserta didik berpendapat bahwa dalam memahami materi kimia yang diajarkan oleh pendidik di kelas dibutuhkan waktu yang cukup lama. Di sisi lain merasa kurang cocok dengan cara dan model pembelajaran yang digunakan pendidik selama pembelajaran di kelas. Peserta didik juga berpendapat bahwa model yang digunakan pendidik terkadang membuat peserta didik bingung dan sulit memahami materi kimia. Termasuk materi kelarutan dan hasil kali kelarutan yang membutuhkan pemahaman konsep dan juga kemampuan 
matematis dalam menyelesaikan soal (Pratiwi dkk., 2015). Dengan demikian, proses pembelajaran kimia di kelas masih kurang maksimal.

Berdasarkan hasil wawancara dengan beberapa guru kimia di MAN 4 Bantul dan SMA Negeri 1 Sewon pada tanggal 10 Januari 2017, menyatakan bahwa penilaian hasil belajar peserta didik selama ini sebatas penilaian kognitif dan afektif yang berkaitan dengan keaktifan peserta didik saat pembelajaran di kelas saja. Sehingga hasil belajar afektif yang lain seperti kreativitas berpikir kimia masih jarang dilakukan.

Analisis lain yaitu hasil observasi di sekolah SMA selama PLP (Program Latihan Profesi) di Bantul, pembelajaran kimia selama ini pada umumnya masih berpusat pada metode ceramah saja. Meskipun banyak metode dan model pembelajaran yang berkembang saat ini, namun ceramah menjadi metode yang banyak digunakan pendidik di kelas. Pada umumnya penggunaan metode ceramah tersebut hanyalah ranah kognitif yang dikembangkan, sedangkan ranah yang lain (afektif dan psikomotorik) kurang dikembangkan, dalam hal ini termasuk kreativitas peserta didik.

Kreativitas merupakan kemampuan yang mencerminkan kelancaran, keluwesan (fleksibilitas), dan orisinalitas dalam berpikir, serta kemampuan untuk mengelaborasi suatu gagasan (Munandar, 1992).

Menurut Mayeseky (1990) konsep kreativitas dapat dilihat dari tiga dimensi, yaitu:

\section{a) Dimensi proses}

Kreativitas adalah suatu proses yang menghasilkan sesuatu yang baru, apakah suatu gagasan atau suatu objek dalam suatu bentuk atau susunan yang baru proses kreatif sebagai munculnya dalam tindakan suatu produk baru yang tumbuh dari keunikan individu di satu pihak, dan di pihak lain tumbuh dari kejadian, orang-orang, dan keadaan hidupnya. Jadi kreativitas sebagai proses berarti bersibuk diri secara kreatif yang menunjukan kelancaran fleksibilitas (keluwesan) dan orisinalitas dalam berpikir dan berperilaku.

\section{b) Dimensi produk}

Definisi pada dimensi produk merupakan upaya mendefinisikan kreativitas yang berfokus pada produk individu baik sifatnya baru ataupun penggabungan/ elaborasi.

\section{c) Dimensi pribadi}

Kreativitas merupakan ungkapan unik dari pribadi sebagai hasil interaksi individu, perasaan, sikap dan perilakunya. Sebagai pribadi, kreativitas mencerminkan keunikan individu dalam pikiran-pikiran dan ungkapanungkapannya. Kreativitas mulai dengan kemampuan individu untuk menciptakan sesuatu yang baru. Biasanya seorang individu yang kreatif memiliki sifat yang mandiri. la tidak merasa terikat pada nilai-nilai dan norma- norma umum yang berlaku dalam bidang keahliannya.

Kreativitas memang sangat dibutuhkan karena dalam pembangunan Indonesia, membutuhkan sumber daya manusia berkualitas yang memiliki kreativitas tinggi. Hal tersebut dibuktikan dengan hasil penelitian internasional yang dilakukan oleh TIMSS (Trend International Mathematics and Science Study) dan PISA (Programme for International Students Assessment) pada tahun 2015 menyampaikan bahwa peningkatan capaian Indonesia tahun 2015 cukup memberikan optimisme, meskipun masih rendah dibanding rerata OECD (Organisation for Economic Co-operation and Development. Berdasar nilai rerata, terjadi peningkatan nilai PISA Indonesia di tiga kompetensi yang diujikan. Peningkatan tebesar terlihat pada kompetensi sains, dari 382 poin pada tahun 2012 menjadi 403 poin di tahun 2015. Dalam kompetensi matematika meningkat dari 375 poin di tahun 2012 menjadi 286 poin di tahun 2015. Kompetensi membaca belum menunjukkan peningkatan yang signifikan, dari 396 di tahun 2012 menjadi 397 poin di tahun 2015. Peningkatan tersebut mengangkat posisi Indonesia 6 
peringkat ke atas bila dibandingkan posisi peringkat kedua dari bawah pada tahun 2012 (OECD, 2016).

\begin{abstract}
Angka-angka tersebut sangat mengkhawatirkan karena pada dasarnya penguasaan dasar-dasar sains dan matematika harus dimiliki oleh setiap individu yang hidup di abad ke-21. Selain itu setiap individu seharusnya memiliki keterampilan yang dibutuhkan di abad ke-21 yang meliputi keterampilan berpikir kritis, kerjasama, komunikasi, dan berpikir kreatif (Pellegrino \& Hilton, 2012:11). Namun, pada umumnya penelitian mengenai kreativitas masih jarang dilakukan.
\end{abstract}

Demi mewujudkan pembelajaran yang efektif, khususnya pada pembelajaran kimia diperlukan suatu model pembelajaran yang tepat sehingga ranah kognitif, afektif, psikomotorik dapat dikembangkan dalam diri peserta didik. Salah satu model pembelajaran yang bisa diterapkan untuk memunculkan ketiga ranah tersebut yaitu, model pembelajaran Treffinger, yang nantinya akan mengukur pengaruh model tersebut terhadap kreativitas berpikir kimia pada peserta didik.

Menurut Ngalimun (2012) model pembelajaran Treffinger dalam peranannya mendorong belajar kreatif yang dapat mengembangkan kreativitas siswa, melibatkan kemampuan afektif dan kognitif yang digambarkan melalui tiga tingkatan berpikir, yaitu:

1. Pada tingkat $\mathbf{I}$ (basic tool), Treffinger memusatkan perhatian pada bagaimana anak dapat berpikir secara divergen atau terbuka tanpa memikirkan bahwa pendapat yang disampaikan benar atau salah. Kemampuan afektif yang dikembangkan meliputi rasa ingin tahu (dapat dilihat dari keaktifan siswa dalam bertanya), keberanian mengambil resiko (keberanian dalam menjawab pertanyaan walaupun jawaban yang disampaikan salah), percaya diri (siswa berani dalam menentukan jawaban yang berbeda dengan jawaban temannya) dan lain sebagainya. Sedangkan kemampuan kognitif yang dapat dikembangkan meliputi kelancaran (dapat dilihat dari waktu yang digunakan anak dalam menjawab dan mengungkapkan gagasan yang berbeda), kelenturan (dilihat dari banyaknya ide atau gagasan yang berbeda yang disampaikan siswa) dan lain sebagainya.

2. Pada tingkat II (practice with process), Treffinger lebih memusatkan perhatiannya pada pengembangan kemampuan penyelesaian masalah dan keterbukaan terhadap perbedaan. Kemampuan afektif pada tingkat ini meliputi keterbukaan perasaan majemuk (yaitu keterbukaan dalam menerima gagasan yang berbeda), meditasi dan kesantaian (kebiasaan dan ketenangan dalam menerima gagasan yang berbeda), penggunaan khayalan dan tamsil (kemampuan berimajinasi dalam menggambarkan masalah yang dihadapi) dan lain sebagainya. Sedangkan kemampuan kognitif yaitu meliputi penerapan (penggunaan apa yang tersedia dalam menyelesaikan masalah yang diberikan), analisis (mendeskripsikan segala masalah yang ada), sintesis (keterampilan memadukan hal yang didapat dengan pengetahuan sebelumnya), evaluasi (penilaian terhadap jawaban teman dan diri sendiri sehingga menghasikan jawaban yang paling tepat) dan lain-lain.

3. Pada tingkat III (real problem), Treffinger memusatkan pada bagaimana anak dapat mengelola dirinya sendiri dan kemampuannya sehubungan dengan keterlibatannya dalam tantangantantangan yang ada dihadapannya. Kemampuan afektif pada tingkat ini meliputi pemberian nilai (berkaitan dengan pengevaluasian diri dan ide-ide sebelumnya), pengikatan diri terhadap hidup produktif (berusaha untuk tetap menghasilkan ide baru dalam setiap kegiatan penyelesaian masalah), dan lainlain. Sedangkan kemampuan kognitif yang dapat dikembangkan meliputi pengajuan pertanyaan secara mandiri (pertanyaan yang timbul dari pemikiran sendiri), pengarahan diri (mampu menentukan 
sendiri langkah-langkah menyelesaikan masalah tanpa terpengaruh penyelesaian dari teman), pengelolaan sumber (menggunakan segala yang ada di sekitar untuk memperoleh jawaban yang diinginkan), dan pengembangan produk (mengembangkan ide yang ada sebelumnya sehingga diperoleh ide baru), dan lain sebagainya.

Menurut Munandar (dalam Ngalimun, 2012) dengan menggunakan ketiga tingkatan kemampuan berpikir dari model Treffinger, siswa dapat membangun ketrampilan, menggunakan kemampuan berpikir kreatifnya dan menemukan penyaluran untuk mengungkapkan kreativitas dalam hidup. Penelitian sebelumnya menunjukkan bahwa model pembelajaran Treffinger memiliki pengaruh terhadap kreativitas siswa, dan diterapkan pada materi yang juga memuat kemampuan matematis seperti yang dilakukan Nisa (2011) yang melakukan penelitian tentang pembelajaran matematika dengan setting model Treffinger untuk mengembangkan kreativitas siswa; Muliyani dkk., (2017) yang meneliti tentang pengaruh model pembelajaran Treffinger terhadap kemampuan berpikir kreatif dan hasil belajar hidrolisis garam siswa kelas XI IPA SMAN 5 Banjarmasin.

\section{METODE PENELITIAN}

Penelitian ini merupakan kuasi eksperimen degan desain non equivalent control group design (Sugiyono, 2010: 116). Penelitian dilakukan untuk mengkaji pengaruh model pembelajaran Treffinger terhadap kreativitas berpikir kimia pada peserta didik. Penelitian dilaksanakan di SMA Negeri 1 Sewon pada bulan April-Mei 2017. Subjek penelitian adalah kelas XI MIA dengan teknik pengambilan sampel secara Cluster Random Sampling, dan diperoleh kelas XI MIA 2 sebagai kelas eksperimen serta XI MIA 3 sebagai kelas kontrol.

Penelitian dilakukan dalam tiga tahapan. Tahap pertama observasi pra penelitian dengan tujuan studi pendahuluan permasalahan yang akan diteliti. Tahap kedua adalah melakukan analisis hasil tes yaitu dengan soal tes essay berupa pre-test dan post-test. Pre-test dilakukan untuk mengetahui kemampuan awal peserta didik. Post-test dilakukan untuk mengetahui kemampuan akhir peserta didik setelah dilakukan perlakuan. Tahap ketiga yaitu analisis sikap kreativitas kimia peserta didik melalui angket self assessment. Analisis data skor hasil belajar menggunakan uji t, sedangkan analisis data skor angket menggunakan uji Mann Whitney.

Kajian pengaruh model pembelajaran Treffinger terhadap hasil tes kreativitas berpikir kimia dilakukan dengan metode tes. Instrumen yang digunakan yaitu soal essay untuk mengukur indikator kreativitas berpikir yaitu kelancaran, orisinil, dan evaluasi.

Indikator kreativitas berpikir kimia pada aspek kelancaran ialah mampu mengemukakan gagasannya dengan lancar, indikator aspek orisinil ialah mampu menggunakan caranya sendiri dalam menyelesaikan masalah dengan proses dan hasil yang benar, sedangkan indikator dari aspek evaluasi ialah mampu mengemukakan alasan dengan benar atas jawaban dari soal yang telah dibuat.

\section{HASIL DAN PEMBAHASAN}

\subsection{Pra Analisis terhadap Subjek Penelitian}

Penelitian ini dilakukan di SMAN 1 Sewon. Berdasarkan wawancara dan observasi, peserta didik mengalami kesulitan dalam mempelajari materi kimia, dan merasa kurang cocok dengan cara dan model pembelajaran yang digunakan pendidik selama pembelajaran di kelas, model yang digunakan pendidik terkadang membuat peserta didik bingung dan sulit memahami materi kimia. Pengembangan kreativitas peserta didik dalam ranah afektif, ranah psikomotorik serta ranah lainnya kurang diperhatikan dan dikembangkan. Dengan demikian, peneliti akan mengimplementasikan model Treffinger di SMAN 1 Sewon terhadap kreativitas berpikir peserta didik.

Jurnal Tadris Kimiya 3, 1 (Juni 2018): 52-61 


\subsection{Perlakuan}

Berdasarkan pra analisis terhadap subjek penelitian, penulis melakukan perlakuan yang berbeda untuk kelas eksperimen dan kelas kontrol. Kelas eksperimen diberi perlakuan menggunakan model Treffinger dan kelas kontrol menggunakan model kooperatif tipe NHT (Numbered Heads Together). Model Treffinger untuk kelas eksperimen ada beberapa tahapan yaitu basic tools, practice with procces, dan working with real problem. Peserta didik di berikan beberapa kegiatan untuk didiskusikan bersama teman-teman satu kelompoknya. Kemudian peserta didik mempresentasikan hasilnya di depan kelas. Sedangkan untuk kelas kontrol menggunakan model koopratif tipe NHT. Model kooperatif menggunakan metode diskusi, lain halnya dengan model Treffinger, model NHT ini dilakukan dengan penomoran peserta didik, setelah peserta didik menyelesaikan soalsoal, kemudian pendidik langsung menyebutkan nomor yang sudah dimiliki oleh peserta didik dalam masing-masing kelompok untuk mempresentasikan hasil diskusinya di depan kelas.
Adapun aspek berpikir kreatif yang diukur antara lain (1) rasa ingin tahu, dengan indikator menanyakan segala sesuatu dengan pertanyaan yang berbeda dari orang lain (orisinil) serta tidak takut mencoba hal-hal yang baru; (2) percaya diri, dengan indikator menyampaikan pendapat dengan jelas dan percaya diri walaupun dalam situasi konflik; (3) keterbukaan terhadap perasaan-perasaan majemuk, dengan tiga indikator yaitu pertama menggunakan gagasan atau masalahmasalah yang rumit, kedua berusaha terus menerus agar berhasil, dan ketiga, senang mencoba jalan yang lebih sulit; (4) keberanian mengambil resiko; dengan tiga indikator yaitu pertama tidak takut gagal, kedua berani mengakui kegagalan dan berusaha lagi, serta ketiga berani mempertahankan gagasan atau pendapatnya walaupun mendapat tantangan atau kritik dan (5) sifat menghargai; dengan dua indikator yaitu menghargai hak-hak sendiri dan hak-hak orang lain, serta menghargai kesempatan-kesempatan yang diberikan. Tabel 1 berikut menunjukkan kisikisi skala kemampuan kreativitas berpikir kimia peserta didik.

Tabel 1. Kisi-Kisi Skala Kemampuan Kreativitas Berpikir Kimia Peserta Didik

\begin{tabular}{|c|c|c|c|}
\hline \multirow{2}{*}{$\begin{array}{c}\text { Aspek } \\
\text { Berpikir } \\
\text { Kreatif }\end{array}$} & \multirow[b]{2}{*}{ Indikator Berpikir Kreatif } & \multicolumn{2}{|c|}{ Pernyataan } \\
\hline & & + & - \\
\hline \multirow[t]{3}{*}{$\begin{array}{l}\text { Rasa ingin } \\
\text { tahu }\end{array}$} & $\begin{array}{l}\text { Menanyakan segala sesuatu } \\
\text { dengan pertanyaan yang } \\
\text { berbeda dari orang lain } \\
\text { (orisinil) }\end{array}$ & $\begin{array}{l}\text { Saya bertanya } \\
\text { mengenai cara lain yang } \\
\text { dapat digunakan ketika } \\
\text { guru menjelaskan cara } \\
\text { mengerjakan soal kimia } \\
\text { di depan kelas }\end{array}$ & $\begin{array}{l}\text { Saya hanya diam } \\
\text { saja ketika guru } \\
\text { menjelaskan cara } \\
\text { menyelesaikan } \\
\text { permasalahan kimia } \\
\text { yang sulit }\end{array}$ \\
\hline & $\begin{array}{l}\text { Tidak takut mencoba hal-hal } \\
\text { yang baru }\end{array}$ & $\begin{array}{l}\text { Saya tidak ragu untuk } \\
\text { menanyakan hal } \\
\text { apapun agar dapat } \\
\text { memahami materi kimia }\end{array}$ & $\begin{array}{l}\text { Saya memilih tidak } \\
\text { menanyakan } \\
\text { kesulitan yang saya } \\
\text { alami saat } \\
\text { memahami materi } \\
\text { kimia }\end{array}$ \\
\hline & & $\begin{array}{l}\text { Saya mempelajari cara } \\
\text { selain yang dicontohkan } \\
\text { oleh guru dalam } \\
\text { menyelesaikan soal } \\
\text { kimia }\end{array}$ & $\begin{array}{l}\text { Saya tidak dapat } \\
\text { mengerjakan soal } \\
\text { kimia yang } \\
\text { diperintahkan oleh }\end{array}$ \\
\hline
\end{tabular}




\begin{tabular}{|c|c|c|c|}
\hline \multirow{3}{*}{$\begin{array}{l}\text { Aspek } \\
\text { Berpikir } \\
\text { Kreatif }\end{array}$} & \multirow{3}{*}{ Indikator Berpikir Kreatif } & \multicolumn{2}{|c|}{ Pernyataan } \\
\hline & & + & - \\
\hline & & & $\begin{array}{l}\text { guru apabila soalnya } \\
\text { sulit }\end{array}$ \\
\hline Percaya diri & $\begin{array}{l}\text { Menyampaikan pendapat } \\
\text { dengan jelas dan percaya diri } \\
\text { walaupun dalam situasi } \\
\text { konflik }\end{array}$ & $\begin{array}{l}\text { Saya berani } \\
\text { mengerjakan soal di } \\
\text { depan kelas }\end{array}$ & $\begin{array}{l}\text { Saya merasa takut } \\
\text { jika mengerjakan } \\
\text { soal di depan kelas }\end{array}$ \\
\hline \multirow{3}{*}{$\begin{array}{l}\text { Keterbukaan } \\
\text { terhadap } \\
\text { perasaan- } \\
\text { perasaan } \\
\text { majemuk }\end{array}$} & $\begin{array}{l}\text { Menggunakan gagasan atau } \\
\text { masalah-masalah yang rumit }\end{array}$ & $\begin{array}{l}\text { Saya memilih soal-soal } \\
\text { kimia yang sulit untuk } \\
\text { belajar }\end{array}$ & $\begin{array}{l}\text { Saya memilih soal- } \\
\text { soal kimia yang } \\
\text { mudah untuk belajar }\end{array}$ \\
\hline & $\begin{array}{l}\text { Berusaha terus menerus } \\
\text { agar berhasil }\end{array}$ & $\begin{array}{l}\text { Saya berusaha } \\
\text { mengerjakan soal kimia } \\
\text { sampai menemukan } \\
\text { jawaban yang benar }\end{array}$ & $\begin{array}{l}\text { Saya menyerah jika } \\
\text { mengerjakan soal } \\
\text { yang sulit }\end{array}$ \\
\hline & $\begin{array}{l}\text { Senang mencoba jalan yang } \\
\text { lebih sulit }\end{array}$ & $\begin{array}{l}\text { Saya senang } \\
\text { mengerjakan soal kimia } \\
\text { sampai menemukan } \\
\text { jawaban yang benar }\end{array}$ & $\begin{array}{l}\text { Saya tidak tertarik } \\
\text { mengerjakan soal } \\
\text { kimia yang sulit }\end{array}$ \\
\hline \multirow[t]{3}{*}{$\begin{array}{l}\text { Keberanian } \\
\text { mengambil } \\
\text { resiko }\end{array}$} & Tidak takut gagal & $\begin{array}{l}\text { Saya mengerjakan soal } \\
\text { kimia tanpa takut gagal } \\
\text { dalam } \\
\text { menyelesaikannya }\end{array}$ & $\begin{array}{l}\text { Saya tidak mau } \\
\text { mengerjakan soal } \\
\text { kimia di depan kelas } \\
\text { karena takut jawaban } \\
\text { saya salah }\end{array}$ \\
\hline & $\begin{array}{l}\text { Berani mengakui kegagalan } \\
\text { dan berusaha lagi }\end{array}$ & $\begin{array}{l}\text { Saya menerima } \\
\text { jawaban guru atau } \\
\text { teman jika memang } \\
\text { jawaban saya ternyata } \\
\text { tidak benar dalam } \\
\text { menyelesaikan soal } \\
\text { kimia walaupun } \\
\text { mendapat kritikan }\end{array}$ & $\begin{array}{l}\text { Saya merasa paling } \\
\text { benar dalam } \\
\text { mengerjakan soal } \\
\text { kimia di depan kelas } \\
\text { walaupun terdapat } \\
\text { kesalahan di dalam } \\
\text { mengerjakannya }\end{array}$ \\
\hline & $\begin{array}{l}\text { Berani mempertahankan } \\
\text { gagasan atau pendapatnya } \\
\text { walaupun mendapat } \\
\text { tantangan atau kritik }\end{array}$ & $\begin{array}{l}\text { Ketika membahas suatu } \\
\text { permasalahan kimia, } \\
\text { saya berani } \\
\text { mempertahankan } \\
\text { pendapat saya kepada } \\
\text { guru jika menurut } \\
\text { pendapat saya adalah } \\
\text { benar }\end{array}$ & $\begin{array}{l}\text { Saya menerima } \\
\text { apabila guru } \\
\text { memberikan } \\
\text { pembenaran jawaban } \\
\text { soal kimia yang saya } \\
\text { kerjakan walaupun } \\
\text { saya yakin jawaban } \\
\text { saya sudah benar }\end{array}$ \\
\hline \multirow[t]{2}{*}{$\begin{array}{l}\text { Sifat } \\
\text { menghargai }\end{array}$} & $\begin{array}{l}\text { Menghargai hak-hak sendiri } \\
\text { dan hak-hak orang lain }\end{array}$ & $\begin{array}{l}\text { Saya memberi } \\
\text { kesempatan yang sama } \\
\text { terhadap diri sendiri dan } \\
\text { teman satu kelompok } \\
\text { untuk menjelaskan cara } \\
\text { menyelesaikan soal } \\
\text { kimia }\end{array}$ & $\begin{array}{l}\text { Saya mengerjakan } \\
\text { soal kimia yang } \\
\text { diberikan guru dalam } \\
\text { diskusi kelompok }\end{array}$ \\
\hline & $\begin{array}{l}\text { Menghargai kesempatan- } \\
\text { kesempatan yang diberikan. }\end{array}$ & $\begin{array}{l}\text { Ketika diskusi kelompok } \\
\text { saya memberikan ide } \\
\text { dan menjelaskan } \\
\text { kepada teman yang }\end{array}$ & $\begin{array}{l}\text { Saat diskusi } \\
\text { kelompok saya lebih } \\
\text { memilih diam dan } \\
\text { mengikuti teman- }\end{array}$ \\
\hline
\end{tabular}




\begin{tabular}{|c|l|l|l|}
\hline $\begin{array}{c}\text { Aspek } \\
\text { Berpikir } \\
\text { Kreatif }\end{array}$ & Indikator Berpikir Kreatif & \multicolumn{1}{|c|}{ Pernyataan } \\
\cline { 2 - 4 } & & \multicolumn{1}{|c|}{-} \\
\cline { 2 - 4 } & & $\begin{array}{l}\text { bertanya bagaimana } \\
\text { cara mengerjakan soal } \\
\text { kimia melalui ide } \\
\text { tersebut }\end{array}$ & $\begin{array}{l}\text { teman dalam } \\
\text { mengerjakan soal } \\
\text { kimia }\end{array}$ \\
\hline \multicolumn{2}{|l}{ Jumlah } & 12 & 12 \\
\hline
\end{tabular}

\subsection{Kajian Pengaruh Model Pembelajaran Treffinger terhadap Kreativitas Berpikir Kognitif Kimia}

Pengaruh model pembelajaran Treffinger terhadap hasil tes kreativitas berpikir peserta didik diukur menggunakan instrumen soal uraian. Hasil tes kreativitas berpikir diperoleh berdasarkan data pre-test dan post-test. Hasil skor pre-test dan post-test dapat dilihat pada Tabel 2 sebagai berikut.

Tabel 2. Hasil Skor Pre-test dan Post-test Kelas Eksperimen dan Kontrol

\begin{tabular}{|l|c|c|}
\hline \multicolumn{1}{|c|}{ Kelas } & $\begin{array}{c}\text { Rata-Rata } \\
\text { pre-test }\end{array}$ & $\begin{array}{c}\text { Rata-Rata } \\
\text { post-test }\end{array}$ \\
\hline Eksperimen & 40,1 & 81,47 \\
\hline Kontrol & 37,9 & 73,63 \\
\hline
\end{tabular}

Berdasarkan hasil pre-test peserta didik diperoleh skor rata-rata kelas eksperimen sebesar 40,1 dan skor rata-rata kelas kontrol sebesar 37,9. Skor rata-rata post-test pada kelas eksperimen sebesar 81,47 dan pada kelas kontrol sebesar 73,63. Berdasarkan nilai rata-rata post-test menunjukkan bahwa hasil tes kreativitas berpikir kelas eksperimen lebih tinggi dibandingkan kelas kontrol. Selanjutnya, analisis dilakukan uji statistika menggunakan statistika parametrik uji t untuk mengkaji pengaruh model pembelajaran Treffinger terhadap hasil tes kreativitas berpikir peserta didik.
Tabel 3. Hasil Post-Test Kreativitas Berpikir Kimia Menggunakan Uji t

\begin{tabular}{|c|c|c|c|}
\hline Tes & $\mathbf{t}$ & $\begin{array}{c}\text { Derajat } \\
\text { kebebasan }\end{array}$ & $\begin{array}{c}\text { Nilai sig. (2- } \\
\text { tailed) }\end{array}$ \\
\hline $\begin{array}{c}\text { Post-test } \\
\text { kreativitas } \\
\text { berpikir } \\
\text { kimia }\end{array}$ & 0,625 & 58 & 0,018 \\
\hline
\end{tabular}

Berdasarkan hasil post-test yang dianalisis menggunakan uji $t$, diperoleh nilai taraf signifikansi sig. (2-tailed) sebesar 0,018. Artinya, nilai signifikansi yang diperoleh kurang dari batas yang digunakan $(<0,05)$. $\mathrm{Hal}$ ini menunjukkan bahwa $\mathrm{H}_{0}$ ditolak dan $\mathrm{H}_{1}$ diterima. Dengan demikian, terdapat perbedaan skor rata-rata kelas eksperimen dengan kelas kontrol, sehingga terdapat pengaruh yang signifikan penggunaan model pembelajaran Treffinger terhadap hasil tes kreativitas berpikir peserta didik.

\subsection{Kajian Pengaruh Model Pembelajaran Treffinger terhadap Sikap Kreativitas Kimia}

Skala kemampuan kreativitas berpikir yang dimaksud dalam penelitian ini adalah skala sikap yang terdiri dari aspek afektif yang ada di model Treffinger yaitu rasa ingin tahu, percaya diri, keterbukaan terhadap perasaanperasaan majemuk, keberanian mengambil resiko, dan sifat menghargai . Data skala kemampuan ini dalam penelitian ini diperoleh melalui angket kreativitas berpikir berupa self assessment. Hasil analisis skor skala kemampuan kreativitas berpikir peserta didik pada kelas eksperimen dan kelas kontrol dapat dilihat pada Tabel 4 sebagai berikut. 
Tabel 4. Hasil Skor Skala Kemampuan Kreativitas Berpikir Kelas EKsperimen dan Kontrol

\begin{tabular}{|l|l|}
\hline \multicolumn{1}{|c|}{ Kelas } & Skor Rata-Rata \\
\hline Eksperimen & 73,23 \\
\hline Kontrol & 65,73 \\
\hline
\end{tabular}

Berdasaran hasil analisis angket skala kemampuan kreativitas berpikir peserta didik kelas eksperimen lebih tinggi dibanding kelas kontrol. Sehingga, terdapat perbedaan skor skala kemampuan kreativitas berpikir antara kelas eksperimen dan kelas kontrol. Analisis selanjutnya dilakukan menggunakan uji statistika non parametrik uji Mann Whitney, yang dapat dilihat pada Tabel 5.

Tabel 5. Hasil Uji Statistika Non parametrik Mann Whitney

\begin{tabular}{|l|r|}
\hline & \multicolumn{1}{|c|}{ nilai } \\
\hline Mann-Whitney U & 257.500 \\
Wilcoxon W & 722.500 \\
Z & -2.849 \\
Asymp. Sig. (2-tailed) & .004 \\
\hline
\end{tabular}

Berdasarkan analisis dengan Mann Whitney diperoleh nilai sig.(2-tailed) sebesar 0,004. Hal ini menunjukkan angka sig $<0,05$ yang berarti terdapat perbedaan antara skor skala kemampuan kreativitas berpikir peserta didik kelas eksperimen dengan kelas kontrol. Dengan demikian, terdapat pengaruh yang signifkan penggunaan model pembelajaran Treffinger terhadap skala kemampuan kreativitas berpikir peserta didik.

\section{KESIMPULAN}

Berdasarkan hasil penelitian yang telah dibahas sebelumnya, diperoleh kesimpulan sebagai berikut:

a. Model pembelajaran Treffinger berpengaruh terhadap kreativitas berpikir kognitif peserta didik.

b. Model pembelajaran Treffinger berpengaruh terhadap sikap kreativitas kimia peserta didik. 


\section{DAFTAR PUSTAKA}

Depdiknas. (2003). Undang-Undang RI Nomor 20 Tahun 2003, tentang Sistem Pendidikan Nasional.

Juliantine, Tite. (2009). Pengembangan Kreativitas Siswa Melalui Implementasi Model Pembelajaran Inkuiri Dalam Pendidikan Jasmani. Jakarta: UPI (Universitas Pendidikan Indonesia).

Mayesky, Mary. (1990). Creative Activities for Young Children. USA: Delmat Publisher Inc.

Muliyani, M., Leny, L., \& Suharto, B. (2017). Pengaruh Model Pembelajaran Treffinger terhadap Kemampuan Berpikir Kreatif Dan Hasil Belajar Hidrolisis Garam Siswa Kelas Xi Ipa Sma Negeri 5 Banjarmasin Tahun Pelajaran 2016/2017. Journal Of Chemistry And Education, 1(1), 86-92.

Munandar, Utami. (1992). Mengembangkan Bakat dan Kreativitas Anak Sekolah. Jakarta: PT. Gramedia.

Ngalimun. (2012). Strategi dan Model Pembelajaran. Banjarmasin. Scripta Cendekia.

Nisa, T. F. (2011). Pembelajaran Matematika dengan Setting Model Treffinger Untuk
Mengembangkan

Siswa. PEDAGOGIA:

Pendidikan, 1(1), 35-48.

Kreativitas

Jurnal

OECD. (2016). PISA 2015 Results in Focus. (https://www.oecd.org/pisa/pisa-2015results-in-focus.pdf), diakses Januari 2017.

Pellegrino, J. W. \& Hilton M. L. (Eds.). (2012). Education for Life and Work: Developing Transferable Knowledge and Skills in the 21st Century. Committee 011 Defining Deeper Learning and 21, Centuiy Skills. National Research Council of the National Academies.

Pratiwi, Y., Mulyani, S., \& Ashadi, A. (2015). Upaya Peningkatan Prestasi Belajar Dan Interaksi Sosial Siswa Dengan Menggunakan Metode Pembelajaran Teams Games Tournament (Tgt) dilengkapi Media Peta Konsep pada Materi Kelarutan dan Hasil Kali Kelarutan Siswa Kelas XI IPA SMA Batik 1 Surakarta. Jurnal Pendidikan Kimia, 4(1), 182-188.

Sugiyono. (2013). Metode Penelitian Manajemen. Bandung: Alfabeta.

Yunita, Sri. (2013). Pengaruh Strategi Pembelajaran Dan Kepriadian Terhadap Hasil Belajar Kognitif Dan Afektif Pendidikan Kewarganegaraan Mahasiswa Jurusan PPKN FIS UNIMED. Medan: UNIMED. 